\title{
Integrating remote sensing and phytosociology of the Atlantic Forest to map a small continental island in southeastern Brazil: subsidies to protect the habitat of critically endangered species
}

\author{
Bruno Coutinho Kurtz ${ }^{1,6}$, Adriana Melo Magalhães ${ }^{2}$, Vinícius da Silva Seabra ${ }^{3}$, Monika Richter ${ }^{4}$ \\ \& Elisa Araujo Penna Caris ${ }^{5}$
}

\begin{abstract}
Queimada Grande (QGI) is a small, legally protected island off the southeastern coast of Brazil that harbors two endemic and critically endangered herpetofauna species: the Golden Lancehead viper (Bothrops insularis) and a hylid frog (Scinax peixotoi); its vegetation, however, has been little studied. We integrated remote sensing and phytosociology of the Atlantic Forest on QGI to characterize the habitat of those two species and support their in situ conservation. QGI retains a mosaic of Atlantic Forest, rock outcrop and anthropogenic vegetation, including invasive alien species, and bare rock surfaces. Mature Atlantic Forest, the preferential habitat of B. insularis and S. peixotoi, currently covers $\sim 28$ ha ( $\sim 50 \%)$ of QGI and shows very low tree richness and an oligarchic structure. The most important species are Guapira opposita, Rudgea minor and Aspidosperma australe. Anthropogenic formations cover $\sim 9 \%$ of the island and do not seem to have expanded in recent years. Based on local conditions, we recommend permanent monitoring of QGI and the use of local tree species in projects to restore the habitat of those two endangered species.
\end{abstract}

Key words: Bothrops insularis, GEOBIA, protected areas, Queimada Grande Island, Scinax peixotoi.

\begin{abstract}
Resumo
Queimada Grande (IQG) é uma pequena ilha, legalmente protegida, ao largo da costa sudeste do Brasil, que abriga duas espécies endêmicas e criticamente ameaçadas da herpetofauna: a jararaca ilhoa (Bothrops insularis) e uma perereca (Scinax peixotoi); sua vegetação, entretanto, tem sido pouco estudada. Nós integramos sensoriamento remoto e inventário fitossociológico da Floresta Atlântica na IQG para caracterizar o habitat destas duas espécies e subsidiar sua conservação in situ. A IQG apresenta um mosaico de Floresta Atlântica, vegetação sobre afloramento rochoso, vegetação antrópica, incluindo espécies exóticas invasoras, e superfícies de rocha nua. A Floresta Atlântica madura, habitat preferencial de B. insularis e S. peixotoi, cobre atualmente $\sim 28$ ha $(\sim 50 \%)$ da ilha e apresenta riqueza arbórea muito baixa e estrutura oligárquica. As espécies mais importantes são Guapira opposita, Rudgea minor e Aspidosperma australe. Formações antrópicas cobrem $\sim 9 \%$ da ilha e não parecem ter se expandido nos últimos anos. Com base nas condições locais, nós recomendamos o monitoramento permanente da IQG e o uso de espécies arbóreas locais em projetos para restaurar o habitat destas duas espécies ameaçadas.
\end{abstract}

Palavras-chave: Bothrops insularis, GEOBIA, Unidades de Conservação, Ilha Queimada Grande, Scinax peixotoi.

\section{Introduction}

Islands have always fascinated scientists, and studies of their biota have produced some of the most important insights concerning the interactions of processes and patterns in biogeography (Lomolino 2000). Although islands show lower

\footnotetext{
'Instituto de Pesquisas Jardim Botânico do Rio de Janeiro, Diretoria de Pesquisa Científica, R. Pacheco Leão 915, 22460-030, Rio de Janeiro, RJ, Brasil. ${ }^{2}$ Instituto Chico Mendes de Conservação da Biodiversidade, ARIE das Ilhas Queimada Pequena e Queimada Grande, R. D. Sebastião Leme 135, 11740-000, Itanhaém, SP, Brasil.

${ }^{3}$ Universidade do Estado do Rio de Janeiro, Faculdade de Formação de Professores, Depto. Geografia, R. Dr. Francisco Portela 1470, 24435-005, São Gonçalo, RJ, Brasil.

${ }^{4}$ Universidade Federal Rural do Rio de Janeiro, Depto. Geografia, R. Roberto da Silveira s/n, 26285-060, Nova Iguaçu, RJ, Brasil.

${ }^{5}$ Universidade Federal do Rio de Janeiro, Inst. Geociências, Depto. Geografia, Av. Brigadeiro Trompowiski s/n, 21945-970, Rio de Janeiro, RJ, Brasil.

${ }^{6}$ Author for correspondence: bkurtz@jbrj.gov.br
} 
species richness per unit area than mainland sites, they often show high degrees of endemism (Wittaker \& Fernández-Palacios 2009). Island biotas are seriously threatened by climate change, habitat loss and, especially, by the introduction of invasive alien species (Kreft et al. 2008; Serafini et al. 2010). Islands are therefore typically recognized as priority sites for biodiversity conservation at both global and regional scales (Wittaker \& Fernández-Palacios 2009).

There are four small, continental shelf islands off the coast of southeastern Brazil (Queimada Grande, Alcatrazes, Vitória and Franceses) that have attracted the interest of various researchers in recent decades as they host at least seven single-island endemic (Brasileiro et al. 2007a,b; Martins et al. 2008; Bataus \& Reis 2011; Barbo et al. 2012, 2016) and critically endangered herpetofauna species (Brasil 2014; IUCN 2015). These islands were connected to the mainland during the Quaternary ice ages when sea levels were significantly lower (see Wittaker \& Fernández-Palacios 2009). During the Holocene, rising sea levels isolated the islands and the ancient populations of continental herpetofauna species, giving rise (through allopatric speciation) to the species now confined to those isolated sites (Marques et al. 2002; Barbo et al. 2012).

Although three of the islands (Queimada Grande, Alcatrazes and Vitória) are now included within federal or state protected areas, in situ conservation of their endemic species depends on a number of additional measures, including the creation of an additional protected area (Franceses; Barbo et al. 2016), effective management of existing sites (e.g., Bataus \& Reis 2011), research and monitoring of their vegetation cover, control of invasive species, and the promotion of ecological restoration of natural habitats.

Our study focused on Queimada Grande Island (QGI), home to the Golden Lancehead vipers [Bothrops insularis (Amaral, 1921)] and a hylid frog (Scinax peixotoi Brasileiro, Haddad, Sawaya \& Martins, 2007). The primary habitat of these species is Atlantic Forest vegetation (Brasileiro et al. 2007a; Martins et al. 2008), which once covered most of QGI. The Atlantic Forest, internationally recognized as a biodiversity hotspot (Mittermeier et al. 2005), originally extended along most of the eastern Brazilian coast, but is now extremely fragmented. While this forest type is still prevalent in QGI, part of its original cover has been replaced by anthropogenic vegetation. There is no phytosociological information available concerning the local Atlantic Forest, which indicates that our knowledge of the vegetation of this island is still incomplete (Martins et al. 2008; Bataus \& Reis 2011; Kurtz et al. 2017), and needs to be extended.

Mapping and monitoring land use and vegetation cover on QGI through remote sensing is strategic to ensuring the $i n$ situ conservation of $B$. insularis and S. peixotoi, and would allow the quantification of changes in the vegetation mosaics of the island (i.e., expansion of anthropogenic areas) and any need for management actions. Complementary phytosociological surveys associated with remote sensing can enhance vegetation cover characterization, adding data on plant species composition and internal structure to the different classes discriminated by the mapping. The evaluation of the phytosociological structure of the local Atlantic Forest can support decision making processes related to the implementation of restoration projects designed to increase the habitat areas of those endemic species, which also represents a strategic initiative within a scenario of global climate change.

Habitat mapping using high resolution satellite imagery can help conservationists accompany endangered species in remote, inaccessible, or dangerous regions such as QGI, and pinpoint areas where conservation efforts should be prioritized. Generally speaking, high spatial resolution is considered to be less than 4 $\mathrm{m}$, and ranges from $0.5-4 \mathrm{~m}$ in the commercial domain for environmental research. QuickBird, IKONOS, GeoEye and WorldView are the commonly used systems (Jensen 2009). High spatial resolution imagery greatly increases the accuracy of identification and characterization of ground objects.

Based on the above considerations, we aimed to produce information about the vegetation on QGI that will be useful for the in situ conservation of $B$. insularis and $S$. peixotoi. To that end, we (1) produced a map of land use and vegetation cover, based on high resolution satellite imagery, to serve as a starting point for monitoring the area; and (2) characterized the phytosociological structure of the local Atlantic Forest (the primary habitat of those species) to identify the most important tree species that could be used in local restoration projects. 


\section{Material and Methods}

Study site

QGI is located $33.2 \mathrm{~km}$ from the southern coast of São Paulo State, in southeastern Brazil (Fig. 1). This small island ( $\sim 57$ ha) has no beaches or sandflats, consisting exclusively of steep slopes and cliffs, with shallow soils and many boulders and rocky outcrops. Its maximum altitude is $210 \mathrm{~m}$ above sea level (Bataus \& Reis 2011). The climate is subtropical with two distinct seasons: rainy and warm (October-March), and then dry and cold (April-September) (Guimarães et al. 2014). In a one-year survey (2007-2008), average monthly temperatures ranged from $18.3{ }^{\circ} \mathrm{C}$ (August) to 27.2 ${ }^{\circ} \mathrm{C}$ (March), while monthly rainfall varied from 0.2 $\mathrm{mm}$ (July) to $135.2 \mathrm{~mm}$ (December) (Marques et al. 2012). The last land-bridge connection of QGI with the mainland occurred about 11,000 years ago (Marques et al. 2002).

The original plant communities on QGI are Atlantic Forest (Dense Ombrophilous Forest, sensu IBGE 1991) and rock outcrop vegetation (see Meirelles et al. 1999). There are also areas covered by anthropogenic vegetation, including a small banana plantation. Recent surveys indicated the presence of 125 terrestrial vascular plant species, including some alien species (Kurtz et al. 2017), in a mosaic pattern resulting from past anthropogenic use of the area. The Brazilian Navy built a lighthouse on QGI in 1909, and lighthouse keepers lived there until 1925. The lighthouse was later automated, and now requires only periodic maintenance (Bataus \& Reis 2011).

QGI was included in the Queimada Pequena and Queimada Grande Islands Relevant Ecological Interest Area (REIA) in 1985 - a Sustainable-Use Federal Conservation Area under the management of the Instituto Chico Mendes de Conservação da Biodiversidade - ICMBio.

We highlight that no data on $B$. insularis and $S$. peixotoi was collected to the present study.

\section{Land use and vegetation cover}

We used QuickBird imagery, acquired on 31 December 2013, to prepare a vegetation map of QGI. The dataset included a composite of one panchromatic band (pan: $760-850 \mathrm{~nm}$ ) with a spatial resolution of $0.6 \mathrm{~m}$, and three multispectral bands (blue: $450-520 \mathrm{~nm}$; green: $520-600 \mathrm{~nm}$; and red: $630-690 \mathrm{~nm}$ ) with spatial resolutions of 2.4 $\mathrm{m}$. The data had a radiometric resolution of 8 bit, and was referenced to the UTM 23S SIRGAS 2000 cartographic system.
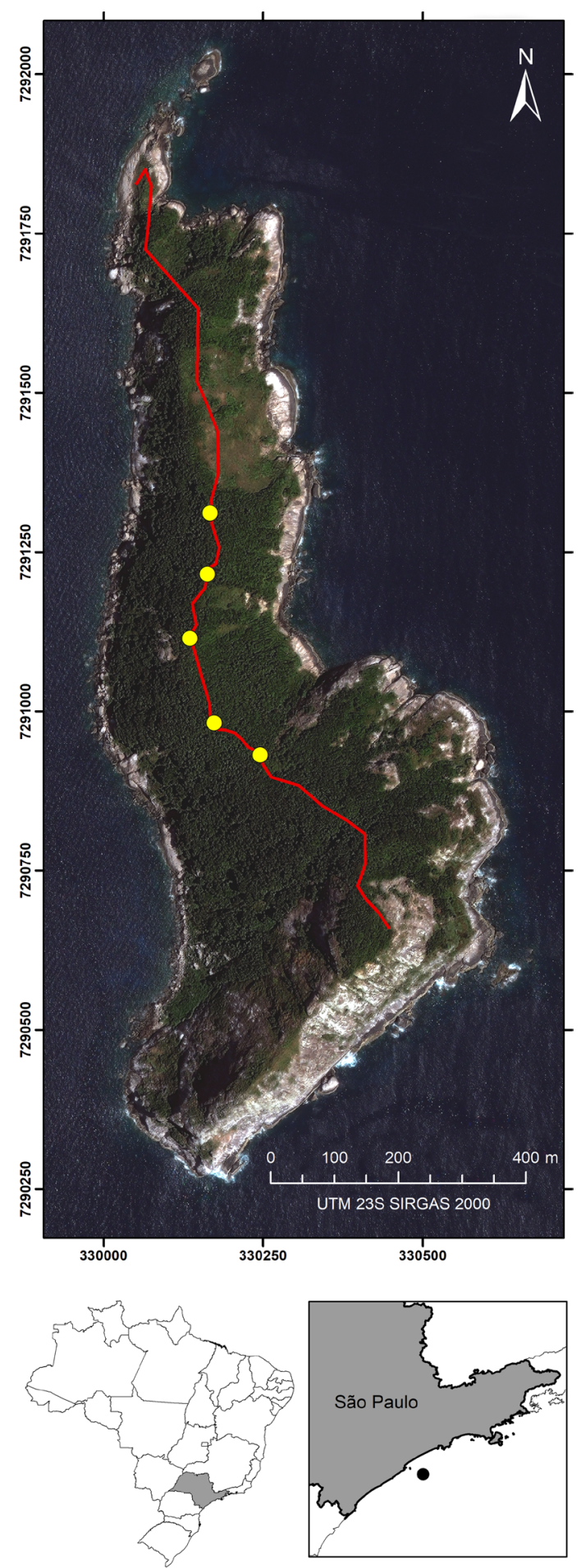

Figure 1 - Location of Queimada Grande Island, São Paulo State, in southeastern Brazil. QuickBird image (1R2G3B), 31 December 2013. The figure shows the main trail (red line) that crosses the island ridge line and the location of the five plots (yellow dots) to the phytosociological survey. 
Geographic object-oriented image analysis (GEOBIA; Blaschke 2010) was applied in the present work, which allows the use of distinct object attributes for their differentiation and interpretation, in contrast to traditional classification methodologies. It becomes possible to determine fuzzy thresholds (not just boolean), and create geometric and legend item hierarchies into the classification process. According to Blaschke (2010), the emergence of classifications based on objects arose from the necessity of analyzing landscapes using spatial objects as interpreted from their spectral responses within their spatial and multiscalar contexts and from terrestrial thematic data (Earth Observation Data). Cruz et al. (2007) pointed out that classifications based on geographic objects simulate visual interpretation, allowing the identification of features based on qualities such as texture, color, metrics, and context. GEOBIA differs from other techniques by allowing multisegmentation, generating hierarchical levels and including aspects of multi-resolution.

GEOBIA was conducted using Definiens 7.0 software (Trimble). The first step consisted of image segmentation, dividing the image into non- overlapping sections in the focal area using multiresolution segmentation algorithm. This algorithm requires several inputs, which were defined through trial-and-error and visual inspection. QuickBird image segmentation was applied with a scale parameter of 50 and a compactness parameter of 0.1 to 0.5 , using equal weights for each spectral band (blue, green and red).

This process considered the digital numbers of the bands used in the classification, followed by the steps of sampling, modeling, and final editing of the mapping. The descriptors utilized in the modeling were the means of the bands, standard deviations of the bands, and maximum differences (Fig. 2). This classification made use of fuzzy and boolean models (Cruz et al. 2007), with some edits in areas where the modeling did not allow the correct separation of classes. These edits likewise included shaded areas.

We developed a hierarchical object-based procedure to classify the QuickBird image into six vegetation/landform classes (Atlantic Ocean, bare rock, rock outcrop vegetation, mature Atlantic Forest, anthropogenic vegetation with herbaceousshrub physiognomy, and Atlantic Forest in early stages of succession). This hierarchical information

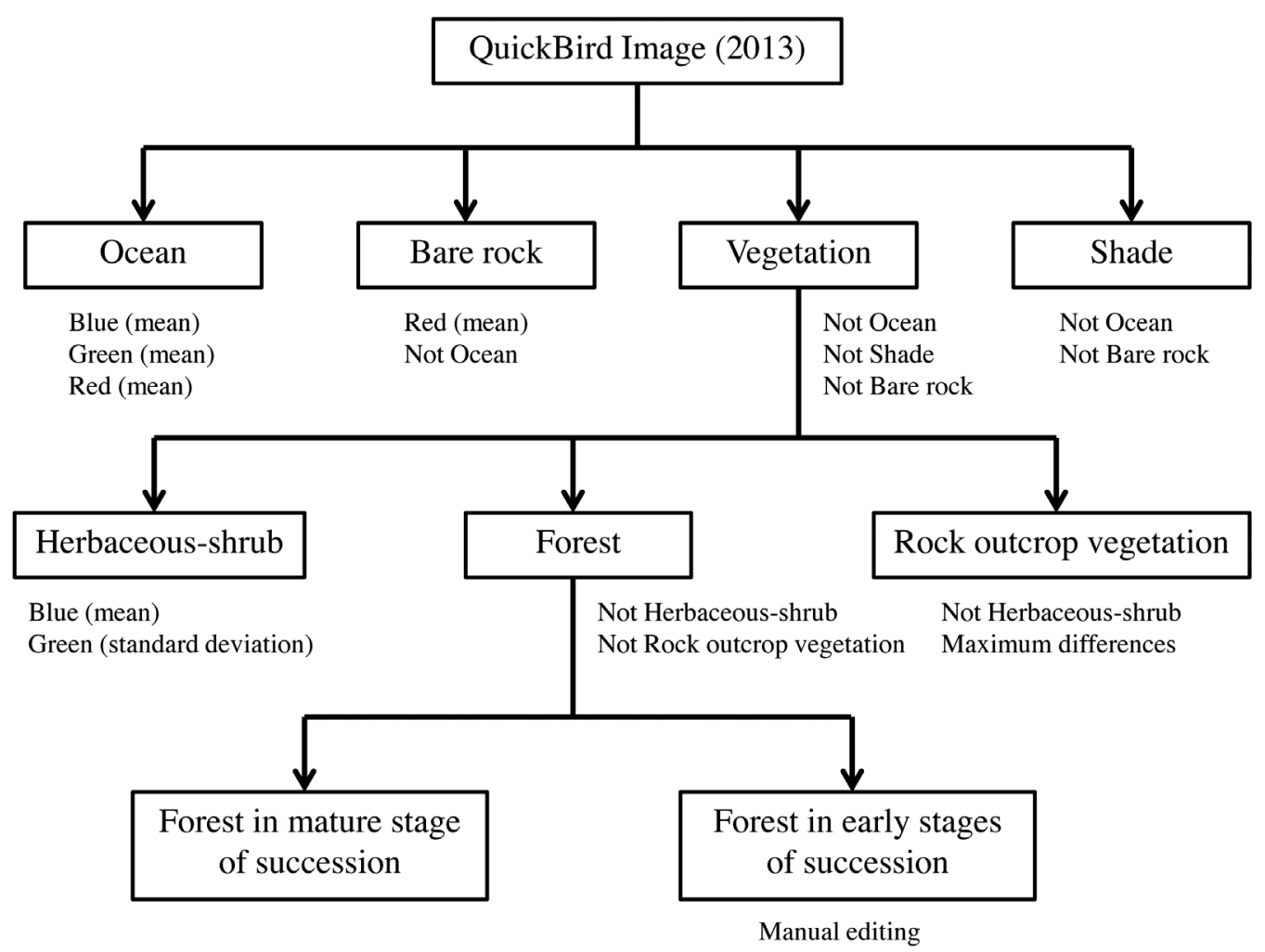

Figure 2 - Class hierarchies and descriptors used in the GEOBIA classification for mapping the use and land cover of Queimada Grande Island, São Paulo state, in southeastern Brazil. 
extraction process required three steps (levels): the first level defined Atlantic Ocean, bare rock, and areas of shade and vegetation cover; at the second level, the vegetation cover was decomposed into anthropogenic vegetation with herbaceous-shrub physiognomy, rock outcrop vegetation, and forested areas; at the third level, the forested areas were separated into mature Atlantic Forest and Atlantic Forest in early stages of succession.

The final edition stage was based on circumnavigations of the island that generated video images and photographs that could subsidize the classification, as well as the imagery and tools of Google Earth. The fieldwork included walks along the principal trail of the island, during which photographs and field notes were taken. It is important to register the difficulties encountered in working on QGI due to its steep landscape and the high densities of the extremely poisonous $B$. insularis (Martins et al.2008), which lives on both the ground and in the trees of the local Atlantic Forest.

The global accuracy and the Kappa index were used to validate the mapping results, both being dependent on a confusion matrix (also called an error matrix) (Congalton 1991). The global accuracy measures the quality of the classifications, but does not reveal the quality of each class. It represents a general measure that does not demonstrate the behavior of each set of individualized data as classes in the mapping. It also does not demonstrate how the accuracy is distributed among the classes. The Kappa index, on the other hand, takes into account the values outside the diagonal of the confusion matrix, therefore considering omission and commission errors (Congalton 1991). Kappa values $<0$ indicate there is no agreement between the two sets of data; Kappa $=1$ indicates total agreement. Intermediate values can be interpreted in terms of the classification described by Landis \& $\operatorname{Koch}$ (1977; Tab. 1).

As such, to validate the mapping, the use and cover polygons were converted into centroids and submitted to the Geostatatiscal Analyst module of the ArcGis 10.1 program, where $20 \%$ of the samples were separated to validate each class. Those samples were subsequently checked against the high-resolution image.

\section{Atlantic Forest phytosociology}

To characterize the structure of the local Atlantic Forest in a mature stage of succession and the most important tree populations, we established five $5 \times 20 \mathrm{~m}$ plots along the trail crossing the
Table 1 - Classification of the Kappa index, according to Landis and Koch (1977), used to validate the mapping of land use and vegetation cover on Queimada Grande Island, São Paulo state, in southeastern Brazil.

\begin{tabular}{cc}
\hline Range of Kappa & Strength of agreement \\
\hline$<0.00$ & Poor \\
$0.00-0.20$ & Slight \\
$0.21-0.40$ & Fair \\
$0.41-0.60$ & Moderate \\
$0.61-0.80$ & Substantial \\
$0.81-1.00$ & Almost perfect \\
\hline
\end{tabular}

island ridge line. These plots were spaced by $\sim 100$ $\mathrm{m}$ and georeferenced by GPS (Fig. 1). All of the studies developed on QGI were performed along this trail, because the potential risks of accidents, as mentioned above. We surveyed and identified all trees with diameters at breast height $(\mathrm{DBH}) \geq$ $3 \mathrm{~cm}$. In order to evaluate our survey effort, we constructed a randomized species accumulation curve, and estimated the number of tree species in the local Atlantic Forest using the Jackknife 1 nonparametric richness estimator (first-order Jackknife; see Colwell \& Coddington 1994). This incidencebased estimator demonstrates good performance and its use in biodiversity studies has been recommended (e.g., Willie et al. 2012). Colwell (2013) noted, however, that estimates of species numbers based on non-parametric estimators should be viewed as lower bounds of the total number of species in a given area. The calculations were performed using EstimateS 9.1 software (Colwell 2013). Voucher specimens were deposited in the RB Herbarium (Instituto de Pesquisas Jardim Botânico do Rio de Janeiro).

We calculated for each tree species the relative density, frequency, dominance, and importance value (Mueller-Dombois \& Ellenberg 1974), as well as Shannon diversity (H') and evenness (J') indices using the natural logarithm (Zar 1996). The calculations were performed using FITOPAC 1.6 software (Shepherd 2006).

\section{Results}

\section{Land use and vegetation cover}

QGI has a projected area of $\sim 57$ ha. We mapped and quantified five classes of land use and vegetation cover: bare rock, rock outcrop vegetation, Atlantic Forest in mature stage of succession, anthropogenic vegetation with herbaceous-shrub 
physiognomy, and Atlantic Forest in early stages of succession (Fig. 3; Tab. 2). The results were satisfactory, even though the image did not possess its original radiometric and spectral characteristics, as the Quickbird image acquired by ICMBio provided only visible bands, in 8 bits (the original scenes are in 11 bits and 8 spectral bands).

Mature Atlantic Forest covers $~ 50 \%$ of QGI and rock outcrop vegetation $\sim 18 \%$; anthropogenic formations (herbaceous-shrub physiognomy and early successional forest) totaled $\sim 9 \%$. Almost $24 \%$ of the area of QGI has no vegetation cover, and was characterized as bare rock. This bare rock class is concentrated along the perimeter of the island, in areas with steep slopes and/or subject to wave action.

Mature Atlantic Forest dominates the phytophysiognomy of QGI, and occurs throughout its altitudinal gradient ( $\sim 0$ to $210 \mathrm{~m})$. This forest demonstrates variable physiognomies depending on the slope, soil accumulation, and wind exposure, but its canopy is generally low, and often open (see the phytosociological description below). The rock outcrop vegetation shows an herbaceous or shrub phytophysiognomy, and occurs as vegetation islands of varied sizes within a bare rocky matrix. These vegetation islands are associated with patches of incipient soil accumulation, so that bare rock sections are also included in this mapping class.

Part of the island's Atlantic Forest was cleared in the past and subsequently replaced by anthropogenic vegetation with an herbaceousshrub physiognomy (including some invasive alien species) that forms a dense cover hindering the establishment of native tree species. This anthropogenic vegetation has also spread to some areas originally covered by rock outcrop vegetation, and now represents $\sim 7 \%$ of the area originally covered by native vegetation on island. In some areas of QGI the vegetation has a closed shrub physiognomy characteristic of Atlantic Forest in early stages of succession, which appears to represent the natural recovery of anthropogenically altered areas.

A total of 1,215 verification points were checked against the high-resolution image to validate the mapping (Tab. 3), with 949 being in the Atlantic Forest in mature stage of succession class as it was most represented on QGI. The global accuracy was 0.95 and the Kappa index was 0.88 . The latter value classified the mapping as almost perfect (see Tab. 1). This result was expected in

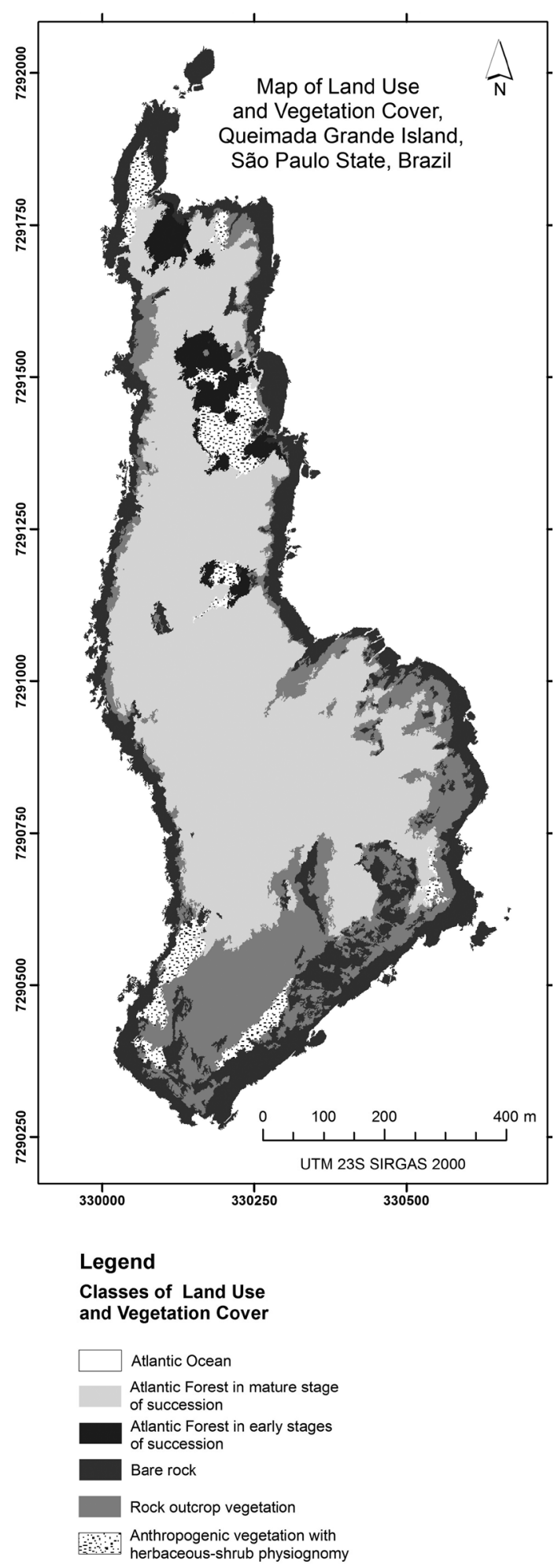

Figure 3 - Land use and vegetation cover map of Queimada Grande Island, São Paulo State, in southeastern Brazil. 
Table 2 - Area (ha) and percentage classes of land use and vegetation cover on Queimada Grande Island, São Paulo state, in southeastern Brazil.

\begin{tabular}{lcc}
\hline Classes & ha & \% \\
\hline Bare rock & 13.31 & 23.6 \\
Atlantic Forest in mature stage of succession & 28.19 & 49.9 \\
Rock outcrop vegetation & 10.13 & 17.9 \\
Anthropogenic vegetation with herbaceous-shrub physiognomy & 2.81 & 5.0 \\
Atlantic Forest in early stages of succession & 2.07 & 3.7 \\
Total & 56.51 & 100 \\
\hline
\end{tabular}

light of the legend used, the size of QGI, and the edition effort employed in the final automatic classification.

\section{Atlantic Forest phytosociology}

The mature Atlantic Forest on QGI shows a very low richness and diversity of tree species, and an oligarchic structure. We surveyed 90 live trees belonging to only eight species and eight families (Tab. 4). Guapira opposita (Vell.) Reitz and Rudgea minor (Cham.) Standl. accounted for $64.4 \%$ of the trees surveyed. Those species, together with Aspidosperma australe Müll. Arg., accounted for more than $70 \%$ of total importance value of the forest. Sideroxylon obtusifolium (Roem. \& Schult.)
T.D. Penn. (VI = 29.8) and Eugenia astringens Cambess. (28.8) showed intermediate importance, while Syagrus romanzoffiana (Cham.) Glassman (11.2), Myrsine guianensis (Aubl.) Kuntze (10.6), and Erythroxylum cuspidifolium Mart. (5.9) were less important in the forest structure. The species accumulation curve (Fig. 4) shows a tendency of stabilization, even considering our low survey effort, suggesting that the most important tree species were adequately surveyed. The Jackknife 1 estimator indicated only 10-11 tree species in the local Atlantic Forest. The H' was only 1.61, and J' was 0.78 .

The projected density was 1,800 trees.ha ${ }^{-1}$ and their basal areas totaled $35.2 \mathrm{~m}^{2} \cdot \mathrm{ha}^{-1}$. The mean tree height was $6.6 \pm 3.4 \mathrm{~m}$ and the mean diameter 13.1

Table 3 - Confusion matrix applied to the map of land use and vegetation cover of Queimada Grande Island, São Paulo state, in southeastern Brazil.

\begin{tabular}{|c|c|c|c|c|c|c|}
\hline Classes & $\begin{array}{c}\text { Atlantic Forest } \\
\text { in mature } \\
\text { stage of } \\
\text { succession }\end{array}$ & $\begin{array}{c}\text { Atlantic Forest } \\
\text { in early stages of } \\
\text { succession }\end{array}$ & $\begin{array}{l}\text { Bare } \\
\text { rock }\end{array}$ & $\begin{array}{c}\text { Rock outcrop } \\
\text { vegetation }\end{array}$ & $\begin{array}{c}\text { Anthropogenic } \\
\text { vegetation with } \\
\text { herbaceous-shrub } \\
\text { physiognomy }\end{array}$ & Total \\
\hline $\begin{array}{l}\text { Atlantic Forest in } \\
\text { mature stage of } \\
\text { succession }\end{array}$ & 921 & 6 & 6 & 15 & 1 & 949 \\
\hline $\begin{array}{l}\text { Atlantic Forest in early } \\
\text { stages of succession }\end{array}$ & 1 & 9 & 0 & 0 & 2 & 12 \\
\hline Bare rock & 1 & 0 & 165 & 4 & 0 & 170 \\
\hline $\begin{array}{c}\text { Rock outcrop } \\
\text { vegetation }\end{array}$ & 0 & 0 & 16 & 66 & 0 & 82 \\
\hline $\begin{array}{c}\text { Anthropogenic } \\
\text { vegetation with } \\
\text { herbaceous-shrub } \\
\text { physiognomy }\end{array}$ & 0 & 0 & 0 & 0 & 2 & 2 \\
\hline Total & 923 & 15 & 187 & 85 & 5 & 1,215 \\
\hline
\end{tabular}


Table 4 - Tree species ( $\mathrm{DBH} \geq 3$ ) surveyed in five $5 \times 20 \mathrm{~m}$ plots in the Atlantic Forest of Queimada Grande Island, São Paulo state, in southeastern Brazil. $\mathrm{N}=$ Number of trees surveyed; RD = Relative density; RDo = Relative dominance; $\mathrm{RF}=$ Relative frequency; IV = Importance value; and $\mathrm{RB}=$ Voucher number.

\begin{tabular}{|c|c|c|c|c|c|c|c|}
\hline Family & Species & $\mathbf{N}$ & RD & RDo & RF & IV & RB \\
\hline Nyctaginaceae & Guapira opposita (Vell.) Reitz & 35 & 38.9 & 46.8 & 23.8 & 109.5 & 636586 \\
\hline Rubiaceae & Rudgea minor (Cham.) Standl. & 23 & 25.6 & 8.4 & 19.1 & 53.0 & 636595 \\
\hline Apocynaceae & Aspidosperma australe Müll. Arg. & 13 & 14.4 & 17.7 & 19.1 & 51.1 & 636611 \\
\hline Sapotaceae & $\begin{array}{l}\text { Sideroxylon obtusifolium (Roem. \& Schult.) } \\
\text { T.D. Penn. }\end{array}$ & 4 & 4.4 & 15.9 & 9.5 & 29.8 & 637081 \\
\hline Myrtaceae & Eugenia astringens Cambess. & 9 & 10.0 & 4.5 & 14.3 & 28.8 & 552194 \\
\hline Arecaceae & Syagrus romanzoffiana (Cham.) Glassman & 2 & 2.2 & 4.3 & 4.8 & 11.2 & Not collected \\
\hline Primulaceae & Myrsine guianensis (Aubl.) Kuntze & 3 & 3.3 & 2.5 & 4.8 & 10.6 & 560747 \\
\hline Erythroxylaceae & Erythroxylum cuspidifolium Mart. & 1 & 1.1 & 0.1 & 4.8 & 5.9 & 587607 \\
\hline
\end{tabular}

$\pm 8.8 \mathrm{~cm}$, indicating that the phytophysiognomy mapped as Atlantic Forest in mature stage of succession on QGI is mainly composed of small trees (maximum height $=16 \mathrm{~m})$, with thin trunks. Twenty-five percent of the trees surveyed were branched ( $2-4$ branches) below breast height. Many trees in the forest were inclined or had fallen over, but were still alive. We also surveyed 11 dead, still standing trees $(10.9 \%$ of the total).

\section{Discussion}

\section{Land use and vegetation cover}

The classification of the high spatial resolution satellite images conducted by GEOBIA allowed us to quantify and spatially define different vegetation

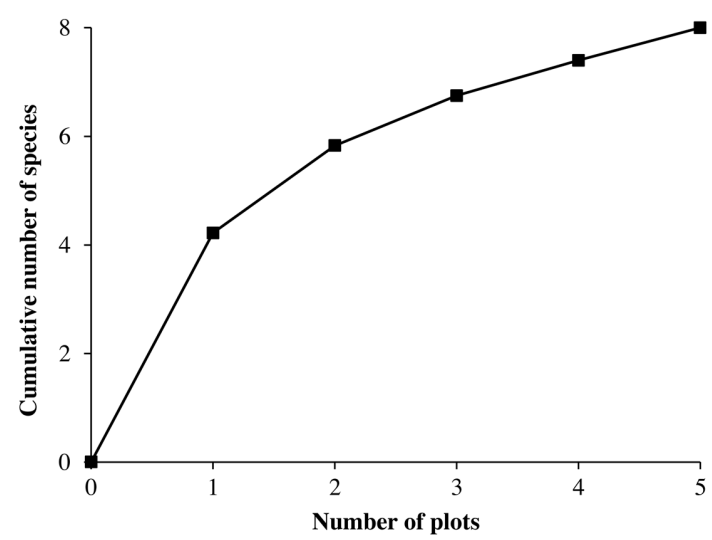

Figure 4 - Accumulation curve of tree species (DBH $\geq 3$ ) surveyed in five $5 \times 20 \mathrm{~m}$ plots in the Atlantic Forest of Queimada Grande Island, São Paulo state, in southeastern Brazil. patches and anthropogenic uses of QGI, revealing the current condition of land cover, which will allow future monitoring, including the dynamics of the natural recovery of the anthropogenically modified areas.

It is important to note that studies with more detailed legends than that produced here will require images with their original radiometric resolutions (QuickBird - 11 bits) and the availability of infrared bands (which are important for vegetation studies). The absence of infrared bands and the degradation of the radiometry of the bands to 8 bits did not affect the quality of the present final information, considering the adopted legend and the fieldwork, which was essential to the completion of a supervised mapping. Additionally, the Atlantic Forest and other ground cover classes were only planimetrically quantified, i.e., the actual topography of the island was not considered, since the calculations for this analysis require digital terrain models with high spatial resolutions still not available for most Brazilian offshore islands. Thus, the real surface area of these classes, as that of QGI, are slightly larger than those quantified here.

Mature Atlantic Forest currently covers $\sim 28$ ha $(\sim 50 \%)$ of QGI, which represents a relatively smaller area of habitat to $B$. insularis and S. peixotoi as compared to the original distribution of this forest, making these species extremely susceptible to stochastic or anthropogenic habitat disturbances that could lead to their extinction (see Brasileiro et al. 2007a). The areas covered by anthropogenic vegetation do not seem to have expanded during the last 10 years. Contrarily, comparison of the 
QuickBird image with an aerial photograph obtained in 2002 (see Fig. 3A in Martins et al. 2008) indicates a slight recovery of the Atlantic Forest in some previously degraded sections of QGI, although this process appears to be very slow. The anthropogenic vegetation is formed, however, by many grasses and other species associated with disturbed areas (Kurtz et al. 2017), and is more fire-prone than the original vegetation on QGI (see Bataus \& Reis 2011). Its persistence is a risk because it increases the probability of occurrence of major fires in the island, thereby threatening the endemic species. So we strongly recommend the control of alien species and the restoration of the anthropogenically modified areas on QGI, as well as permanent monitoring of land use and island vegetation cover at intervals of no more than 10 years - with more frequent monitoring if reductions in the local Atlantic Forest cover are detected.

The islands of Alcatrazes (180 ha; $35 \mathrm{~km}$ from the coast), Vitória (220 ha; $25 \mathrm{~km}$ ), and Franceses (16 ha; $3.6 \mathrm{~km}$ ) are very similar to QGI in many aspects. All four islands are included in the Atlantic Forest complex (Scarano 2002) and their floras show strong continental influences as a result of recurring contacts during the Quaternary period (e.g., Ferreira et al. 2007; Kurtz et al. 2017). Although they have experienced different historical uses, all of them currently display similar land cover, i.e., native vegetation mosaics (Atlantic Forest, shrub, and rock outcrop vegetation) and anthropogenic formations (Pompéia et al. 1994; Ferreira et al. 2007; Sartorello 2010; Fundação Florestal 2015; ICMBio 2017). As with QGI, those three islands have been populated with invasive alien species that cover significant areas in each.

Franceses Island, where the Lancehead viper Bothrops sazimai sp. nov. occurs (Barbo et al. 2016), is not legally protected, and still suffers anthropogenic pressures because of human settlement and tourism; twenty percent of its area was classified as disturbed in 2004, with signs of continuing expansion (Ferreira et al. 2007). Alcatrazes, which is home to an endemic Lancehead viper (Bothrops alcatraz Marques, Martins \& Sazima, 2002) and two endemic frogs [Scinax alcatraz (Lutz, 1973) and Cycloramphus faustoi Brasileiro, Haddad, Sawaya \& Sazima, 2007] (Brasileiro et al. 2007b; Bataus \& Reis 2011), was just very recently fully protected (ICMBio 2017), and parts of the island had been shelled during artillery exercises by the Brazilian Navy. Vitória Island has a long history of human occupation and some areas been used for subsistence agriculture and are occupied by the homes of a few local residents (Fundação Florestal 2015). The Lancehead viper Bothrops otavioi Barbo, Grazziotin, Sazima, Martins \& Sawaya, 2012, is endemic to that island (Barbo et al. 2012). As such, the insular endemics on those islands are critically endangered by anthropogenic pressures on their naturally very limited habitats (Brasil 2014; IUCN 2015). There are already maps of land use and vegetation cover available for the islands of Alcatrazes (ICMBio 2017), Vitória (Sartorello 2010; Fundação Florestal 2015), and Franceses (Ferreira et al. 2007), which can likewise be used as starting points for monitoring those islands.

\section{Atlantic Forest phytosociology}

Even considering the total number of tree species on the island ( $\mathrm{S}=17$; Kurtz et al. 2017), many of which apparently rare locally, this richness is extremely low compared to those usually found in continental remnants of Atlantic Forest formation (Kurtz \& Araújo 2000; Scudeller et al. 2001; Urbanetz et al. 2010). This insular Atlantic Forest shows an unusual oligarchic structure, with strong co-dominance of G. opposita, R. minor, and $A$. australe. Diversity, basal area, height, and diameter values are also much lower than those found on the continent (e.g., Kurtz \& Araújo 2000). These features are most likely related to a combination of local factors such as the steepness of island slopes, incipient soils, constant winds, the possible absence of pollinators/dispersers, and the small size of the island and its distance from the mainland (which is the natural source of tree species propagules) (Lomolino 2000; Kreft et al. 2008; Wittaker \& Fernández-Palacios 2009).

The limited data available concerning the flora of small continental islands $(\leq 220$ ha) in southeastern Brazil (Ferreira et al. 2007; ICMBio 2008, 2017; Sartorello 2010; Bovini et al. 2014) indicates few tree species per island: e.g., Alcatrazes ( $\mathrm{S}=39$; ICMBio 2017); Vitória $(\mathrm{S}=28$; Sartorello 2010); and Franceses $(\mathrm{S}=$ 23; Ferreira et al. 2007). The Atlantic Forest on those islands is usually composed of trees that are smaller than those on the mainland (Ferreira et al. 2007; ICMBio 2017). The same factors indicated above are apparently restricting the tree growth on those three islands, although with different intensities. The proximity of Franceses Island to the coast, for example, means that it has been isolated for less time and undoubtedly receives 
more propagules arriving from the continent, generating a slightly richer tree flora than seen on QGI ( $\mathrm{S}=23$ vs. 17) - a larger island, but much farther from the mainland. The relatively lower number of tree species recorded for Vitória Island (the largest of the four islands), however, may be related to a lower sampling effort and a history of selective logging of some timber species (Fundação Florestal 2015) that are currently rare or locally extinct. Only M. guianensis seems to be recurrent on those four islands. The few phytosociological data on the vegetation of Alcatrazes suggest that G. opposita is also important in the local Atlantic Forest (ICMBio 2017).

Since there is no evidence that the Atlantic Forest on QGI was ever completely cleared in the past (except the areas now occupied by anthropogenic vegetation), it probably represents a pristine forest, a type of insular climax. For this reason, this phytophysiognomy was classified as Atlantic Forest in mature stage of succession. The high population density of $B$. insularis has probably restricted more intense exploitation of the island's natural resources and helped protect it.

The local Atlantic Forest seems to provide an adequate supply of small fleshy fruits and arillated seeds for migratory passerines (see Montanhini 2010), which represent a key animal group on QGI and the main prey of $B$. insularis (Marques et al. 2012). The tree species surveyed on QGI are, in general, widespread in the continental Atlantic Forest (BFG 2015), and some of them have the potential for use in forest restoration in southeastern Brazil (Moraes et al. 2013) and should be prioritized in any conservation/propagation projects on QGI. These tree species include G. opposita, S. romanzoffiana, M. guianensis, Cupania oblongifolia Mart., Trema micrantha (L.) Blume, and Gallesia integrifolia (Spreng.) Harms (the last three species surveyed by Kurtz et al. 2017). Except for the latter species, all of those trees produce small diaspores appreciated by the avifauna (Pineschi 1990; Lorenzi 1992, 1998, 2000; Passos \& Oliveira 2004). The planting of these species would therefore not only accelerate forest regeneration processes (Rodrigues et al. 2009) but would also provide additional food resources for migratory passerines, and therefore improve food resource availability for $B$. insularis.

Obviously, any Atlantic Forest restoration initiatives on QGI should follow the published recommendations and protocols available for this forest type (e.g., Rodrigues et al. 2009; Moraes et al. 2013). Being an island, and an established conservation site, we recommend the use of local genetic material. The areas mapped here as anthropogenically modified vegetation with a herbaceous-shrub physiognomy and Atlantic Forest in early stages of succession should be targets for the restoration projects.

Despite the recent publication of some phytosociological data on the vegetation of Alcatrazes (ICMBio 2017), there is no available information concerning the structures of the plant communities or their principal populations on Vitória and Franceses, forestalling any restoration efforts. We therefore strongly recommend the development of phytosociological studies focusing on the small fragments of Atlantic Forest on those islands. Based on this information it could be possible to promote habitat restoration and contribute to the in situ conservation of their critically endangered herpetofauna species. These initiatives, plus the monitoring of the dynamics of the vegetation mosaics and the control of invasive alien species on Queimada Grande, Alcatrazes, Vitória, and Franceses islands, should necessarily involve research institutions, governmental and funding agencies, and non-governmental organizations. Some of these initiatives have already been recommended in the management plans for Alcatrazes (ICMBio 2017) and Vitória (Fundação Florestal 2015).

\section{Conclusions}

We integrated remote sensing based on high resolution satellite imagery and phytosociological survey to discriminate, quantify, and characterize the mature Atlantic Forest on QGI, the natural habitat of the critically endangered species $B$. insularis and $S$. peixotoi. We also mapped other local classes of land use and vegetation cover, highlighting areas covered by anthropogenically modified vegetation. The local Atlantic Forest shows a very low richness and diversity of tree species, and an unusual oligarchic structure in which Guapira opposita, Rudgea minor, and Aspidosperma australe predominate. These features are most likely related to a combination of limiting factors characteristic of insular conditions. Finally, our results may be used by the ICMBio as a starting point for the monitoring and management of this protected area, contributing to the in situ conservation of its endangered species. These activities should include the control of invasive alien species and the restoration of the anthropogenically modified areas. 


\section{Acknowledgments}

We thank the REIA team of Queimada Pequena and Queimada Grande Islands, as well as A. Lourenço Júnior (in memoriam), C.R. Abrahão, R.A. Dias, and V.M. Uhlig for logistical support and security during excursions to QGI, and the ICMBio for the research permit (SISBIO - 44050-1) on QGI.

\section{References}

Barbo FE, Grazziotin FG, Sazima I, Martins M \& Sawaya RJ (2012) A new and threatened insular species of lancehead from southeastern Brazil. Herpetologica 68: 418-429.

Barbo FE, Gasparini JL, Almeida AP, Zaher H, Grazziotin FG, Gusmão RB, Ferrarini JMG \& Sawaya RJ (2016) Another new and threatened species of lancehead genus Bothrops (Serpentes, Viperidae) from Ilha dos Franceses, Southeastern Brazil. Zootaxa 4097: 511-529.

Bataus YSL \& Reis ML (orgs.) (2011) Plano de ação nacional para a conservação da herpetofauna insular ameaçada de extinção. ICMBio, Brasília. 124p.

BFG - The Brazil Flora Group (2015) Growing knowledge: an overview of seed plant diversity in Brazil. Rodriguésia 66: 1085-1113.

Blaschke T (2010) Object based image analysis for remote sensing. ISPRS Journal of Photogrammetry and Remote Sensing 65: 2-16.

Bovini MG, Faria M, Oliveira RR \& Kurtz BC (2014) Floristic diversity of the Cagarras Islands Natural Monument, Rio de Janeiro, Brazil. Check List 10: 366-373.

Brasileiro CA, Haddad CFB, Sawaya RJ \& Martins M (2007a) A new and threatened species of Scinax (Anura: Hylidae) from Queimada Grande Island, southeastern Brazil. Zootaxa 1391: 47-55.

Brasileiro CA, Haddad CFB, Sawaya RJ \& Sazima I (2007b) A new and threatened island-dwelling species of Cycloramphus (Anura: Cycloramphidae) from southeastern Brazil. Herpetologica 63: 501510.

Brasil (2014) Portaria MMA n 444, 17 December 2014. Diário Oficial da União, edição 245, seção 1: 121 126, 18 December 2014.

Colwell RK (2013) EstimateS: Statistical estimation of species richness and shared species from samples, version 9. Available at <http://purl.oclc.org/ estimates $>$. Access on 12 February 2016.

Colwell RK \& Coddington JA (1994) Estimating terrestrial biodiversity through extrapolation. Philosophical Transactions of the Royal Society B 345: 101-118.

Congalton RG (1991) A review of assessing the accuracy of classifications of remotely sensed data. Remote Sensing of Environment 37: 35-46.
Cruz CBM, Vicens RS, Seabra VS, Reis RB, Faber OA, Richter M, Arnaut PKE \& Araújo M (2007) Classificação orientada a objetos no mapeamento dos remanescentes da cobertura vegetal do bioma Mata Atlântica, na escala 1:250.000. In: Anais do XIII Simpósio Brasileiro de Sensoriamento Remoto. INPE, Florianópolis. Pp. 5691-5698.

Ferreira AL, Coutinho BR, Pinheiro HT \& Thomaz LD (2007) Composição florística e formações vegetais da Ilha dos Franceses, Espírito Santo. Boletim do Museu de Biologia Mello Leitão (Nova Série) 22: 25-44.

Fundação Florestal (2015) Parque Estadual de Ilhabela: plano de manejo, vol. principal. Fundação Florestal, São Paulo. 835p.

Guimarães M, Munguía-Steyer R, Doherty Jr. PF, Martins M \& Sawaya RJ (2014) Population dynamics of the critically endangered golden lancehead pitviper, Bothrops insularis: stability or decline? PLoS ONE 9: e95203.

IBGE - Instituto Brasileiro de Geografia e Estatística (1991) Manual técnico da vegetação brasileira. IBGE, Rio de Janeiro. 92p.

ICMBio - Instituto Chico Mendes de Conservação da Biodiversidade (2008) Plano de manejo da Estação Ecológica dos Tupiniquins. ICMBio, Brasília. 403p.

ICMBio - Instituto Chico Mendes de Conservação da Biodiversidade (2017) Plano de manejo da Estação Ecológica Tupinambás e Refúgio de Vida Silvestre do Arquipélago de Alcatrazes. 2 vols. ICMBio, Brasília. 203p.

IUCN - International Union for Conservation of Nature (2015) The IUCN red list of threatened species, version 2015-4. Available at $<$ http://www. iucnredlist.org/>. Access on 27 June 2015.

Jensen JR (2009) Sensoriamento remoto do ambiente: uma perspectiva em recursos terrestres. Parêntese, São José dos Campos. 598p.

Kreft H, Jetz W, Mutke J, Kier G \& Barthlott W (2008) Global diversity of island floras from a macroecological perspective. Ecology Letters 11: 116-127.

Kurtz BC \& Araújo DSD (2000) Composição florística e estrutura do componente arbóreo de um trecho de Mata Atlântica na Estação Ecológica Estadual do Paraíso, Cachoeiras de Macacu, Rio de Janeiro, Brasil. Rodriguésia 51: 69-112.

Kurtz BC, Souza VC, Magalhães AM, Paula-Souza J, Duarte AR \& Joaquim-Jr. GO (2017) The vascular flora and vegetation of Queimada Grande Island, São Paulo state, southeastern Brazil. Biota Neotropica 17: e20170336.

Landis JR \& Koch GG (1977) The measurement of observer agreement for categorical data. Biometrics 33: 159-174. 
Lomolino MV (2000) A call for a new paradigm of island biogeography. Global Ecology \& Biogeography 9: 1-6.

Lorenzi H (1992) Árvores brasileiras: manual de identificação e cultivo de plantas arbóreas nativas do Brasil. Plantarum, Nova Odessa. 352p.

Lorenzi H (1998) Árvores brasileiras: manual de identificação e cultivo de plantas arbóreas nativas do Brasil. Vol. 2. $2^{\text {nd }}$ ed. Plantarum, Nova Odessa. 352p.

Lorenzi H (2000) Plantas daninhas do Brasil: terrestres, aquáticas, parasitas e tóxicas. $3^{\text {rd }}$ ed. Instituto Plantarum, Nova Odessa. 608p.

Marques OAV, Martins M \& Sazima I (2002) A jararaca da Ilha da Queimada Grande. Ciência Hoje 31: 56-59.

Marques OAV, Martins M, Develey PF, Macarrão A \& Sazima I (2012) The golden lancehead Bothrops insularis (Serpentes: Viperidae) relies on two seasonally plentiful bird species visiting its island habitat. Journal of Natural History 46: 885-895.

Martins M, Sawaya RJ \& Marques OAV (2008) A first estimate of the population size of the critically endangered lancehead, Bothrops insularis. South American Journal of Herpetology 3: 168-174.

Meirelles ST, Pivello VR \& Joly CA (1999) The vegetation of granite rock outcrops in Rio de Janeiro, Brazil, and the need for its protection. Environmental Conservation 26: 10-20.

Mittermeier RA, Gil PR, Hoffman M, Pilgrim J, Brooks T, Mittermeier CG, Lamoreux J \& Fonseca GAB (2005) Hotspots revisited: Earth's biologically richest and most endangered terrestrial ecoregions. The University of Chicago Press, Chicago. 392p.

Montanhini AM (2010) Avifauna da Ilha da Queimada Grande, SP: diversidade, estrutura trófica e sazonalidade. Dissertação de Mestrado. Universidade Estadual Paulista, São José do Rio Preto. 65p.

Moraes LFD, Assumpção JM, Pereira TS \& Luchiari C (2013) Manual técnico para a restauração de áreas degradadas no estado do Rio de Janeiro. Jardim Botânico do Rio de Janeiro, Rio de Janeiro. 84p.

Mueller-Dombois D \& Ellenberg H (1974) Aims and methods of vegetation ecology. John Wiley \& Sons, New York. 547p.

Passos L \& Oliveira PS (2004) Interaction between ants and fruits of Guapira opposita (Nyctaginaceae) in a Brazilian sandy plain rainforest: ant effects on seeds and seedlings. Oecologia 139: 376-382.
Pineschi RB (1990) Aves como dispersores de sete espécies de Rapanea (Myrsinaceae) no maciço do Itatiaia, estados do Rio de Janeiro e Minas Gerais. Ararajuba 1: 73-78.

Pompéia SL, Pereira A, Rossi L, Aidar MPM, Moraes RP \& Santos RP (1994) A vegetação da Ilha dos Alcatrazes - São Paulo. In: Anais do III Simpósio de Ecossistemas da Costa Brasileira: Subsídios a um Gerenciamento Ambiental. ACIESP, Serra Negra. Vol. 2. Pp. 54-67.

Rodrigues RR, Brancalion PHS \& Isernhagen I (orgs.) (2009) Pacto pela restauração da Mata Atlântica: referencial dos conceitos e ações de restauração florestal. LERF/ESALQ, Instituto BioAtlântica, São Paulo. 256p.

Sartorello R (2010) Ilhas do litoral norte do estado de São Paulo: paisagem e conservação. Dissertação de Mestrado. Universidade de São Paulo, São Paulo. 160p.

Scarano FR (2002) Structure, function and floristic relationships of plant communities in stressful habitats marginal to the Brazilian Atlantic rainforest. Annals of Botany 90: 517-524.

Scudeller VV, Martins FR \& Shepherd GJ (2001) Distribution and abundance of arboreal species in the atlantic ombrophilous dense forest in Southeastern Brazil. Plant Ecology 152: 185-199.

Serafini TZ, França GB \& Andriguetto-Filho JM (2010) Ilhas oceânicas brasileiras: biodiversidade conhecida e sua relação com o histórico de uso e ocupação humana. Revista da Gestão Costeira Integrada 10: 281-301.

Shepherd GJ (2006) Fitopac 1.6 (com FitopacShell): versão preliminar. UNICAMP, Campinas. 64p.

Urbanetz C, Tamashiro JY \& Kinoshita LS (2010) Floristic composition and similarity analysis of an Atlantic rain forest fragment in Cananéia, São Paulo state, Brazil. Revista Brasileira de Botânica 33: 639-651.

Willie J, Petre CA, Tagg N \& Lens L (2012) Evaluation of species richness estimators based on quantitative performance measures and sensitivity to patchiness and sample grain size. Acta Oecologica 45: 31-41.

Wittaker RJ \& Fernández-Palacios JM (2009) Island biogeography: ecology, evolution, and conservation. $2^{\text {nd }}$ ed. Oxford University Press, Oxford. 401p.

Zar JH (1996) Biostatistical analysis. $3^{\text {rd }}$ ed. Prentice Hall, New Jersey. 662p. 